\title{
Efficiency of sweet flag and curly parsley volatile oils compared with synthetic insecticides against Ceroplastes rusci on Ruellia plants
}

\author{
I.A. Mohamed', G.S. Mohamed ${ }^{2}$, E.Y. Abdul-Hafeez ${ }^{3, *}$ and O.H.M. Ibrahim ${ }^{3}$
}

Summary Ruellia simplex plant is grown for its aesthetic features including flowers, leaves and overall foliage appearance. The fig wax scale Ceroplastes rusci L. (Hemiptera: Coccidae) was detected for the first time in Egypt on R. simplex. Mineral oil, diazinon, thiamethoxam + chlorantraniliprole, and essential oils extracted from Acorus calamus and Petroselinum crispum, were compared for their ability to control the insect. Results indicated that reduction percentage increased gradually until day 7 after the treatment regarding adults, nymphs and their total. The maximum efficacy of the mineral oil, and thiamethoxam + chlorantraniliprole, was noticed 21 days after treatment, followed by A. calamus oil. Efficacy of P. crispum oil and diazinon reached more than $86 \%$ after 21 days and more than $90 \% 28$ days after treatment. At 28 days, $A$. calamus oil reached its maximum efficacy. Plants treated with thiamethoxam + chlorantraniliprole were the tallest plants and possessed significantly higher number of branches and leaves, and leaf pigments followed by those treated with mineral oil or A. calamus oil. A. calamus oil and thiamethoxam + chlorantraniliprole were proved as promising compounds tested for the first time in controlling $C$. rusci.

Additional keywords: Acorus calamus, essential oil, fig wax scale insect, Petroselinum crispum, Ruellia simplex

\section{Introduction}

One of the newly introduced flowering ornamental plants into Egypt is Ruellia simplex C. Wright 'Katie', syn. Ruellia brittoniana Leonard 'Katie' known as Dwarf Mexican Petunia. It is a very popular landscape plant, effectively grown as an annual flowering plant as a pond marginal, in beds and borders, as free-blooming plant in large containers; it may be grown indoors as a houseplant (Gilman, 1999; Ezcurra and Daniel, 2007; Anonymous, 2015a).

The fig wax scale, Ceroplastes rusci L. (Hemiptera: Coccoidea: Coccidae), is a polyphagous pest that attacks a wide range of plants from at least 21 different families of

1 Plant Protection Dept., Faculty of Agriculture, Assiut University, 71526, Egypt

2 Plant Protection Dept., Faculty of Agriculture, South Valley Univ., Egypt

${ }^{3}$ Ornamental Plants and Landscape Gardening Dept., Fac. Agric., Assiut Univ., 71526, Egypt

* Corresponding author: noresam_2000@yahoo.com, eyhafeez@aun.edu.eg fruits, ornamental plants and high economic value trees. It is well known as a serious pest of figs (Ficus spp.) and other commercial fruit crops in the Mediterranean region and in several agricultural regions of the world. It attacks almost all parts of the host plant and can cause death of the weakened and heavily infested leaves and shoots. Sooty moulds developing on the scale honeydew can reduce photosynthetic activity of leaves (AlMomany and Al-Antary, 2008; Vu et al., 2006; Deng et al., 2015; Ismail et al., 2015). In addition to the direct plants physical damage, C. rusci is known to carry plant viruses ( $\mathrm{La}$ Notte et al., 1997).

Chemical control is the main and effective tool used worldwide for controlling scale insects and mealybugs (Franco et al., 2009). Mineral oils have been proved highly effective for controlling scale insects in a variety of fruits and orrnamental plants all over the world including Egypt (Ismail et al., 2015). Various organophosphorous compounds such as diazinon were also found to be effective against scale insects (Abd- 
Rabou et al., 2012). However, some of these compounds exhibited harmful effect on the natural enemies of the pests and other non-target organisms (Satar et al., 2013). Recently, a new insecticide was developed by mixing thiamethoxam and chlorantraniliprole. Thiamethoxam is a neonicotinoid insecticide found highly effective in controlling scale insects, mealybugs and other sucking pests (Abbas et al., 2014; Mohamed et al., 2015). Chlorantraniliprole is a relatively new anthranilic diamide systemic insecticide which has a potent insecticidal activity against a wide range of pests including Hemiptera (Sattelle et al., 2008).

Increasing emphasis is being placed on the potential usage of natural products such as essential oils as more environmentally friendly pesticides alternative to synthetic insecticides. Concerns about phytotoxicity of these oils and lack of confidence in their efficacy are the main reasons beyond the reluctance of many growers to incorporate such compounds in their pest management programs (Miller and Uetz, 1998). Essential oils from different plants have been known to show insecticidal, bactericidal, fungicidal and herbicidal properties (Bakkali et al., 2008). Of these compounds, volatile oil from the perennial plant Acorus calamus L. (Araceae), common name sweet flag, and Petroselinum crispum (Mill.) Fuss var. crispum (Apiaceae), common name curly parsley, are considered in the current research. The essential oil of sweet flag has been found by several authors such as Liu et al. (2013) to exhibit toxicity, chemosterilant, antifeedant and growth inhibitory effects against a variety of insect pests. Asarone as ether is the main component of the oil which is used for the control of pests and bacteria (Abdul-Hafeez and Egorov, 2012). Parsley essential oil is obtained from the leaves and seeds of curly parsley (Petropoulos et al., 2004). It was found by many authors such as Mulugeta et al. (2015) to have insecticidal, nematicidal, antimicrobial and antiradical activities.

Accordingly, the main objective of the current research was to compare the efficiency of natural volatile oils of both A. cal- amus and $P$. crispum with famous synthetic insecticides viz; mineral oil, thiamethoxam + chlorantraniliprole, diazinon, as foliar application for controlling the fig wax scale on $R$. simplex plants.

\section{Material and Methods}

Pot plants of $R$. simplex heavily infested with the fig wax scale were used. The plants were grown in $20-\mathrm{cm}$ pots and kept under lathhouse conditions (70\% shade) over the period of the experiment. The current study was conducted at the Experimental Farm of the Department of Ornamental Plants and Landscape Gardening, Assiut University, Egypt during 2014 and 2015.

\section{Tested compounds}

The insecticides tested were $20 \%$ thiamethoxam $+20 \%$ chlorantraniliprole (Voliam flexi 40\% WG obtained from Syngenta Crop Protection, Switzerland); diazinon (Diazin 60\% EC obtained from Medmac for Manufacturing Agricultural Chemicals and Veterinary Products Company Ltd. Jordan) and KZ mineral oil 95\% EC (Kafr El-Zayat Co., Egypt). The essential oils of $A$. calamus and $P$. crispum were extracted by the hydro-distillation method using a Clevenger-type Apparatus (Clevenger, 1928) at the Laboratory of Medicinal Plants, Faculty of Agriculture, Assiut University. Roots of $A$. calamus were collected from Kazan state (Tatarstan Republic, Russia). The vegetative parts were collected from parsley plants grown at the Floriculture Experimental Farm, Assiut University. Samples were shredded into small pieces and distilled. The essential oil was collected in dark glass vessels and kept at $-40^{\circ} \mathrm{C}$ until it was used.

\section{Bioassays}

Both essential oils were tested at the rate of $2 \mathrm{ml} / /$ water and emulsified with $1 \mathrm{ml}$ of Tween-80. The rates of the commercial formulations were $0.4 \mathrm{~g}$ thiamethoxam + chlorantraniliprole/l water, $5 \mathrm{ml}$ diazinone/l water and $15 \mathrm{ml}$ mineral oil/l water. Also a 
non-treated control was used. Each treatment comprised of 3 plants and was replicated 3 times. The insecticides and essential oils were sprayed using a hand laboratory sprayer equipped with a flat-fan nozzle. Data regarding the number of live nymphs and adults of $C$. rusci were recorded before application and after 1, 3, 7, 15, 21, 28 and 35 days. Population reduction percentage was calculated according to Henderson and Tilton's formula (1955). Upon completion of the experiment, vegetative growth characteristics were recorded i.e. plant height, branch number/plant and leaf number/plant. In addition, leaf content of chlorophyll $a, b$ and carotenoids was determined as $\mathrm{mg} / \mathrm{g}$ fresh weight according to the acetone incubation method described by Krishnan et al. (1996) and Dere et al. (1998).

\section{Statistical analysis}

Data were statistically analyzed using two-way split-plot ANOVA (Snedecor and Cochran, 1989) where time of observations was considered as sub-plot and tested com-

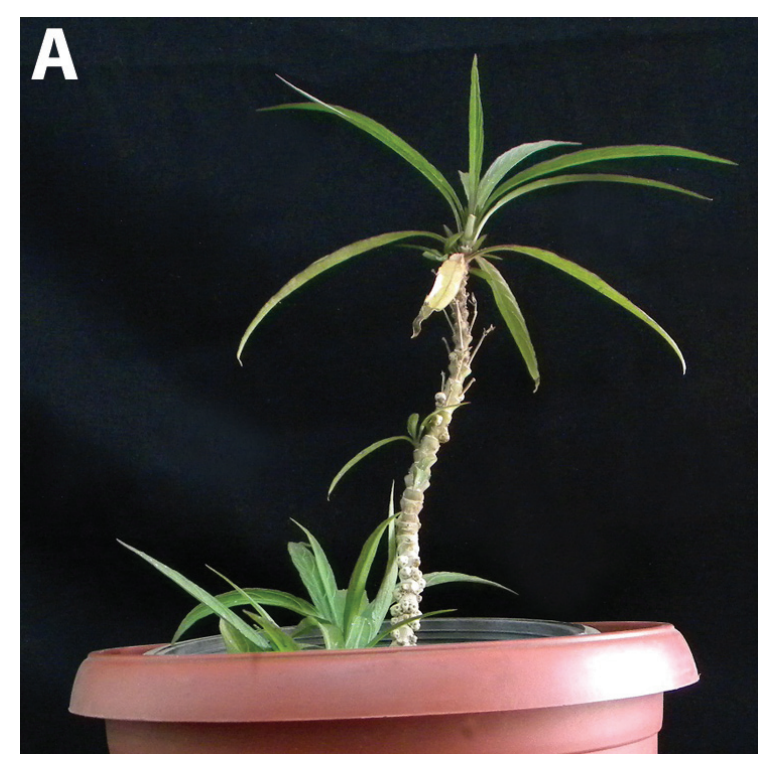

Figure 1. Non-treated Ruellia simplex plants infested with nymphs and adults of Ceroplastes rusci. A: infested whole plant, B: infested stem with all insect stages (eggs, nymphs and adults), C: infested leaf. Images $B$ and ( are under binocular stereoscope (magnification 10X). pounds as main-plot. Means were separated by least significant difference (L.S.D.) at $5 \%$ level of significance according to Steel and Torrie (1982). Statistical analysis was performed using Statistix 8.1 program.

\section{Results}

\section{Reduction \% of C. rusci}

Ceroplastes rusci was detected and recorded on $R$. simplex plants grown at the Floriculture Experimental Farm, Faculty of Agriculture, Assiut University, Egypt. To our knowledge, this is the first report of $C$. rusci on $R$. simplex plants in Egypt. Figure 1 illustrates an infested plant and different insect stages on stems and leaves.

Results revealed that one day after treatment, all tested compounds induced reductions of nymph population of C. rusci (2.08 $-6.09 \%)$, which did not significantly differ among them (Table 1). Among all tested compounds, only A. calamus oil showed mortality against the adult stage, which
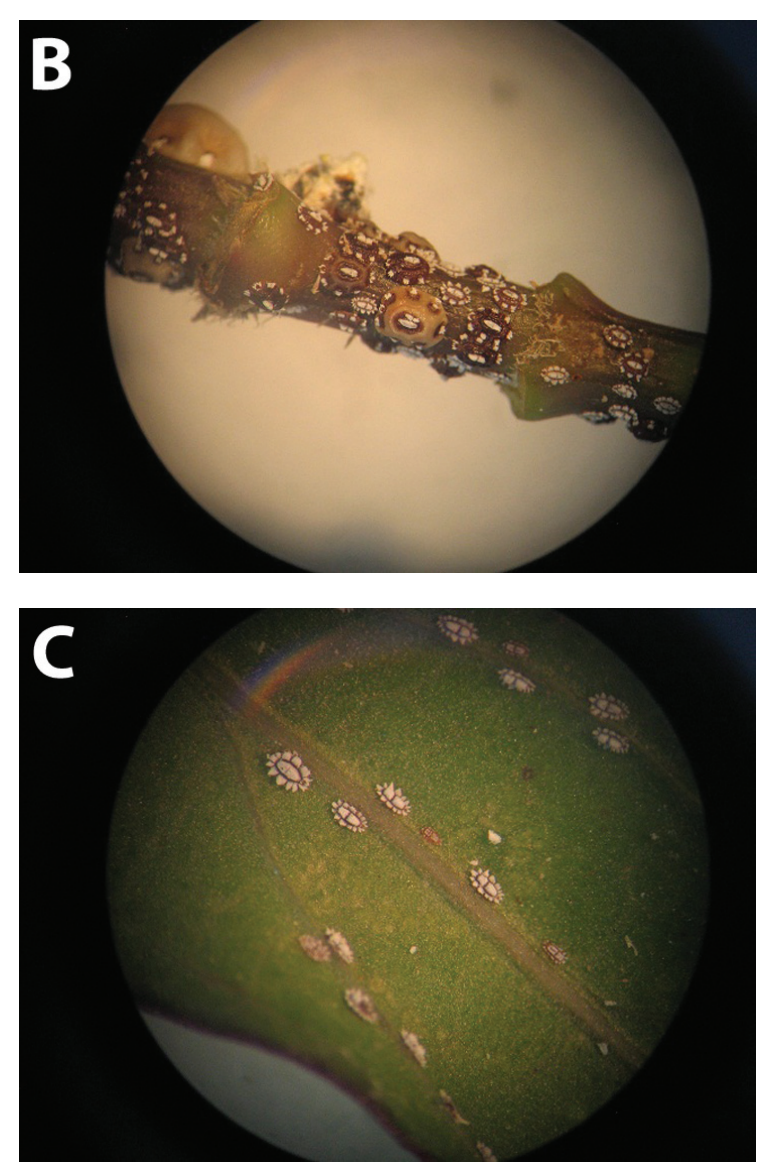
Table 1. Effect of synthetic insecticides and volatile oils on the reduction percentage of nymph, adult and total populations of Ceroplastes rusci on Ruellia simplex plants.

\begin{tabular}{|c|c|c|c|c|}
\hline \multirow{2}{*}{ 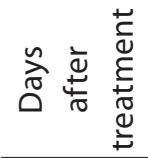 } & \multirow{2}{*}{ Compounds } & \multicolumn{3}{|c|}{ Percentage of Reduction (\%) } \\
\hline & & Nymphs & Adults & Total \\
\hline \multirow[t]{5}{*}{1} & Thiamethoxam + chlorantraniliprole & 4.71 & 0.00 & 2.36 \\
\hline & Diazinon & 2.08 & 0.00 & 1.04 \\
\hline & Mineral Oil & 5.57 & 0.00 & 2.79 \\
\hline & Petroselinum crispum Oil & 4.38 & 0.00 & 2.19 \\
\hline & Acorus calamus Oil & 6.09 & 0.39 & 3.24 \\
\hline \multirow[t]{5}{*}{3} & Thiamethoxam + chlorantraniliprole & 30.92 & 34.66 & 32.79 \\
\hline & Diazinon & 13.85 & 20.19 & 17.02 \\
\hline & Mineral Oil & 33.37 & 33.54 & 33.46 \\
\hline & Petroselinum crispum Oil & 23.05 & 13.37 & 18.21 \\
\hline & Acorus calamus Oil & 34.99 & 45.58 & 40.29 \\
\hline \multirow[t]{5}{*}{7} & Thiamethoxam + chlorantraniliprole & 66.22 & 60.75 & 63.48 \\
\hline & Diazinon & 40.62 & 48.38 & 44.50 \\
\hline & Mineral Oil & 76.13 & 76.14 & 76.13 \\
\hline & Petroselinum crispum Oil & 48.92 & 33.95 & 41.43 \\
\hline & Acorus calamus Oil & 73.81 & 75.28 & 74.55 \\
\hline \multirow[t]{5}{*}{15} & Thiamethoxam + chlorantraniliprole & 90.88 & 88.33 & 89.61 \\
\hline & Diazinon & 67.37 & 76.30 & 71.84 \\
\hline & Mineral Oil & 91.92 & 93.99 & 92.95 \\
\hline & Petroselinum crispum Oil & 69.25 & 57.48 & 63.37 \\
\hline & Acorus calamus Oil & 93.00 & 91.22 & 92.11 \\
\hline \multirow[t]{5}{*}{21} & Thiamethoxam + chlorantraniliprole & 98.02 & 99.34 & 98.68 \\
\hline & Diazinon & 87.56 & 92.18 & 89.87 \\
\hline & Mineral Oil & 98.59 & 99.64 & 99.11 \\
\hline & Petroselinum crispum Oil & 89.68 & 86.63 & 88.16 \\
\hline & Acorus calamus Oil & 96.15 & 97.45 & 96.80 \\
\hline \multirow[t]{5}{*}{28} & Thiamethoxam + chlorantraniliprole & 97.82 & 96.22 & 97.02 \\
\hline & Diazinon & 93.79 & 92.87 & 93.33 \\
\hline & Mineral Oil & 93.69 & 95.73 & 94.71 \\
\hline & Petroselinum crispum Oil & 95.32 & 90.54 & 92.93 \\
\hline & Acorus calamus Oil & 98.02 & 99.35 & 98.68 \\
\hline \multirow[t]{5}{*}{35} & Thiamethoxam + chlorantraniliprole & 90.66 & 92.01 & 91.34 \\
\hline & Diazinon & 89.31 & 84.75 & 87.03 \\
\hline & Mineral Oil & 85.71 & 83.83 & 84.77 \\
\hline & Petroselinum crispum Oil & 89.00 & 86.98 & 87.99 \\
\hline & Acorus calamus Oil & 94.57 & 95.76 & 95.17 \\
\hline \multirow[t]{3}{*}{ LSD 0.05} & Time & 2.38 & 5.40 & 2.87 \\
\hline & Compounds & 1.93 & 2.76 & 2.03 \\
\hline & Time $\times$ Compounds & 5.10 & 7.29 & 5.38 \\
\hline
\end{tabular}

gave $0.39 \%$ reduction. These results indicate that nymphs of $C$. rusci were more susceptible to the all tested compounds than the adult stage one day after treatment.
Three days after treatment, $A$. calamus provided the highest reduction percentage against nymphs and adults, followed by the mineral oil and thiamethoxam + chlo- 
rantraniliprole (Table 1, Figure 2). Diazinon was found to be the least toxic compound, caused the least reduction against nymphs and adults (Table 1).

Seven days after treatment, a slight change in the efficacy order of the tested compounds was noticed; the mineral oil was the most toxic compound on nymphs and adults followed by $A$. calamus oil, and then thiamethoxam + chlorantraniliprole. Both diazinon and $P$. crispum oil were found comparatively the least effective compounds (Table 1).

Fifteen days after treatment, the evaluated compounds revealed the same efficacy order as at three days after treatment for adults and in total (nymphs and adults). For nymphs, the A. calamus oil showed the highest reduction percentage, followed by the mineral oil and thiamethoxam + chlorantraniliprole with non significant differences among the three compounds. However, they significantly differed from diazinon and the $P$. crispum oil, which recorded the least reduction percentages (Table 1 ).

Twenty one days after the treatment, the mineral oil, thiamethoxam + chlorantraniliprole and $A$. calamus oil exhibited the great- est potent against nymphs, adults and in total, where they gave $96.8-99.11 \%$ reduction with non-significant differences between them. Diazinon and P. crispum oil had the least effect (Table 1).

Twenty eight days after treatment, $A$. calamus oil and thiamethoxam + chlorantraniliprole recorded the highest reduction on nymphs and adults (over 96\%). The P. crispum oil, the mineral oil and diazinon showed also high reduction percentages (over 90\%) of nymphs, adults and in total.

Thirty five days after treatment, $A$. calamus oil and thiamethoxam + chlorantraniliprole induced the highest reduction in the nymph, adult and total populations, with non-significant differences between them. Non-significant differences were noticed between both P. crispum oil and diazinon reduction percentages of adult, nymph and total populations. The mineral oil exhibited the least efficacy on all insect stages.

In general, adult, nymph and total reduction percentage of $C$. rusci increased gradually until day 21 after the treatment. After 7 days, A. calamus oil, thiamethoxam + chlorantraniliprole and mineral oil exhibited the best results while $P$. crispum oil and diazinon

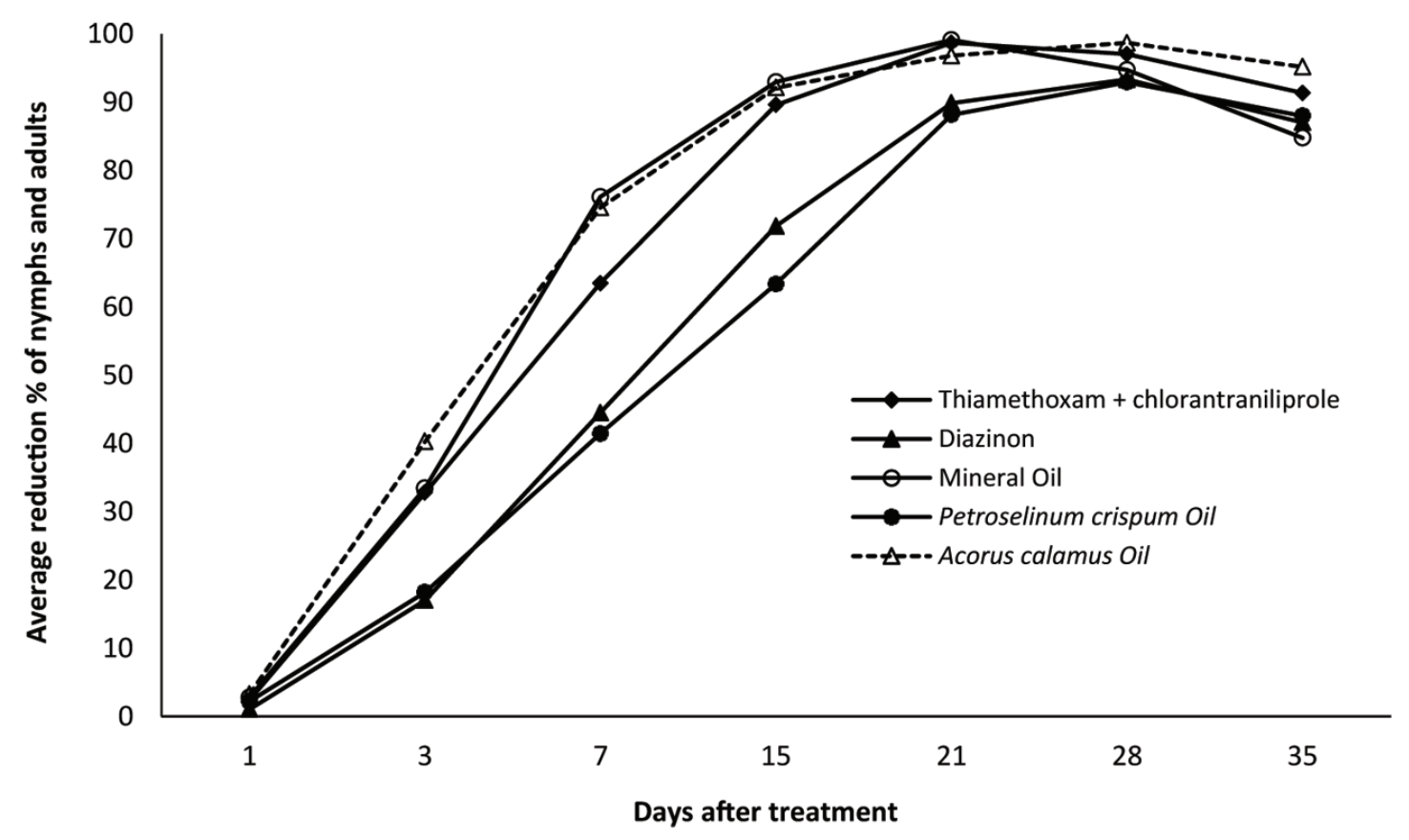

Figure 2. Effect of synthetic insecticides and volatile oils on total reduction percentage of nymphs and adults of Ceroplastes rusci on Ruellia simplex plants. 
showed the lowest ones. The highest reduction percentage was recorded with the same three compounds between day 15 and 28, reaching more than $90 \%$ in all cases except the reduction percentage in adult and total with thiamethoxam + chlorantraniliprole after 15 days. The maximum efficacy of mineral oil, and thiamethoxam + chlorantraniliprole, was noticed after 21 days (more than $98 \%$ ), followed by $A$. calamus oil (more than $96 \%$ ) with no significant differences. Efficacy of both P. crispum oil and diazinon increased gradually and reached more than $86 \%$ after 21 days and more than $90 \%, 28$ days after the treatment. At 28 days, $A$. calamus reached its maximum efficacy (more than 98\%). The effect of all tested compounds started to decrease gradually after 28 days.

\section{Plant growth}

Data presented in Table 2 show some vegetative characteristics of Ruellia plants infested with $C$. rusci after the treatment with pesticides or volatile oils. Plants treated with thiamethoxam + chlorantraniliprole were the tallest ones and possessed the highest number of branches and leaves followed by those treated with the mineral oil or A. calamus oil. Moreover, the plants treated with $A$. calamus oil exhibited slight leaf yellowing suggesting an evidence of slight phytotoxicity, which completely recovered about two weeks after the treatment.

Leaf content of chlorophyll a, b and carotenoids further support the superiority of thiamethoxam + chlorantraniliprole and $A$. calamus oil in alleviating the negative impact of the insect on growth quality of Ruellia plant. Chlorophyll a reached the highest values in the plants treated with thiamethoxam + chlorantraniliprole, A. calamus oil and mineral oil, respectively. While chlorophyll $b$ had the same trend, carotenoids' content was found significantly higher in A. calamus oil, mineral oil and P. crispum oil (Table 2).

\section{Discussion}

Ruellia plant is grown for its aesthetic features including flowers, leaves and overall foliage appearance, which was found to be highly affected by the infestation with $C$. rusci. Different compounds were tested for their ability to control insect and alleviate its negative influence on plant growth and appearance.

Mineral oil, the only recommended pesticide for C. rusci in Egypt, exhibited high efficacy in controlling C. rusci nymphs and adults; the highest efficacy was recorded 21 days after treatment which decreased after 28 days of the treatment. Inhibition of insect

Table 2. Final quality parameters and leaf content of chlorophyll $a, b$ and carotenoids of $R u$ ellia simplex plants after the treatment with synthetic insecticides and volatile oils.

\begin{tabular}{l|cccccc}
\hline \multirow{2}{*}{ Treatments } & \multicolumn{7}{|c}{ Measurements } \\
\cline { 2 - 7 } & $\begin{array}{c}\text { Plant } \\
\text { height } \\
\mathrm{cm}\end{array}$ & $\begin{array}{c}\text { Branch } \\
\text { number/ } \\
\text { plant }\end{array}$ & $\begin{array}{c}\text { Leaf } \\
\text { number/ } \\
\text { plant }\end{array}$ & $\begin{array}{c}\text { Chl. } \\
\text { "a" } \\
\mathrm{mg} / \mathrm{g} \mathrm{FW}\end{array}$ & $\begin{array}{c}\text { Chl. } \\
\text { "b" } \\
\mathrm{mg} / \mathrm{g} \mathrm{FW}\end{array}$ & $\begin{array}{c}\text { Carotenoids } \\
\mathrm{mg} / \mathrm{g} \mathrm{FW}\end{array}$ \\
\hline Control (untreated) & $15.00 \mathrm{c}$ & $3.67 \mathrm{~b}$ & $33.33 \mathrm{~d}$ & $0.222 \mathrm{~d}$ & $0.072 \mathrm{~d}$ & $0.154 \mathrm{c}$ \\
Thiamethoxam + & $16.90 \mathrm{a}$ & $5.57 \mathrm{a}$ & $55.23 \mathrm{a}$ & $0.427 \mathrm{a}$ & $0.127 \mathrm{ab}$ & $0.173 \mathrm{bc}$ \\
chlorantraniliprole & $16.73 \mathrm{a}$ & $3.77 \mathrm{~b}$ & $38.16 \mathrm{c}$ & $0.285 \mathrm{c}$ & $0.072 \mathrm{~d}$ & $0.157 \mathrm{c}$ \\
Diazinon & $15.83 \mathrm{~b}$ & $5.77 \mathrm{a}$ & $52.53 \mathrm{a}$ & $0.397 \mathrm{a}$ & $0.117 \mathrm{bc}$ & $0.214 \mathrm{a}$ \\
Mineral Oil & $15.93 \mathrm{~b}$ & $3.50 \mathrm{~b}$ & $45.17 \mathrm{~b}$ & $0.327 \mathrm{~b}$ & $0.102 \mathrm{c}$ & $0.192 \mathrm{ab}$ \\
Petroselinum crispum Oil & $16.50 \mathrm{ab}$ & $5.67 \mathrm{a}$ & $48.43 \mathrm{~b}$ & $0.422 \mathrm{a}$ & $0.138 \mathrm{a}$ & $0.223 \mathrm{a}$ \\
Acorus calamus Oil & 0.79 & 0.99 & 3.90 & 0.038 & 0.017 & 0.033 \\
LSD 0.05 &
\end{tabular}

* Means in the same column followed by the same letter are not significantly different at $p=0.05$, LSD test. 
growth was strongly related with significant improvement in plant growth characteristics including plant height, number of branches and leaves, and leaf content of chlorophylls $a$ and $b$. In agreement with our results, several previous studies revealed that mineral oils application gave satisfactory results in controlling scale insects such as C. rusci in figs (Ismail et al., 2015), soft wax scale Ceroplastes destructor Newstead on citrus (Blank et al., 1997), the guava soft scale Pulvinaria psidii Mask on guava (Aly et al., 1984), the mango soft scale Klifia acuminata Signoret and P. psidii on mango (Nada et al., 1990), and the nigra scale Parasaissetia nigra Nietner and the cottony camellia scale Pulvinaria floccifera Westwood on guava and mango (Abd-Rabou et al., 2012). It was also proved effective against scale insects in Egypt such as olive scale (Parlatoria oleae Colvee) (Ibrahim, 1990). The mode of action of mineral oils is usually assumed to be suffocation (Davidson et al. 1991). In some cases, oils also may act as poisons through their interacting with the fatty acids of the insect and their interfering with normal metabolism (Helmy et al., 1992; Cranshaw and Baxendale, 2011). Nevertheless, other compounds showed promising results which significantly surpassed those of the mineral oil.

The volatile oil of $A$. calamus exhibited significantly high efficacy against nymphs and adults of $C$. rusci, exceeding $90 \%$ inhibition 21 days after treatment (more than 96\%) and reaching its maximum efficacy (more than 98\%) after 28 days; the efficacy declined after 35 days, yet it was still superior to other tested compounds. The decrease in insect populations led to a noticeable recovery in overall plant appearance as could be inferred from the data of plant vegetative characteristics. A. calamus oil has been shown by several previous studies to exhibit insecticidal activity caused by its active component (asarone) against several insect species of economic importance (Hossain et al., 2008; Liu et al., 2013). It induced antifeedant and growth inhibitory effects in Peridroma saucia (Koul and Isman, 1990), Spodoptera litura Fab. (Thanapandian et al., 2011) and Tribolium castaneum
(Chandel et al., 2001). Moreover, Saxena et al. (1977) found that asarone possessed insect chemosterilant properties. The active component of $A$. calamus ( $\alpha$ - and $\beta$-asarone) inhibited both spermatogenesis and oogenesis causing sterility in a variety of insect species such as the melan fly Bactrocera cucurbitae (Nair et al., 2001) and the kelp fly Coelopa frigida (Ramos-Ocampo and Hsia, 1986).

Our results provided an evidence that thiamethoxam and chlorantraniliprole is a promising agent which exhibited excellent control of $C$. rusci insect on $R$. simplex plants with no evidence of phytotoxicity. Treated plants were characterized by the best growth characteristics including plant height, number of branches and leaves, and leaf content of chlorophylls $a$ and $b$. This mixture is a new insecticide, containing active substances which belong to neonicotinoids and anthranilic diamide with different mode of actions (Saglam et al., 2013). Our findings are in accordance with those obtained by several previous studies such as Awamleh et al. (2009). Ahmed et al. (2005) and Taha et al. (2012) also demonstrated the efficacy of thiamethoxam on the green date palm pit scale (Asterolicanium phoenicis Rao) on date palm. Chlorantraniliprole is very effective against several Lepidopteran, Coleopteran and Hemipteran pests that attacked fruit, vegetable and ornamental plants (Sattelle et al., 2008). In addition, chlorantraniliprole may have some ovicidal effect against fig wax scale. The efficacy of chlorantraniliprole on egg hatching has been found in other pests such as the diamondback moth, Plutella $x y$ lostella L. (Han et al., 2012), and Tribolium confusum Jacquelin du Val (Saglam et al., 2013). Chlorantraniliprole has a novel mode of action that interrupts the normal muscle contraction causing impaired regulation, paralysis and ultimately death of sensitive insect species or causing feeding cessation, lethargy, and muscle paralysis, finally insect death (Lahm et al., 2005; Cordova et al., 2006).

In comparison with the other tested compounds, both P. crispum oil and diazinon exhibited the least reduction percentages of all insect stages. They had no signif- 
icant effect on the insect until 15 days after the treatment then the effect increased at 21 days and reached the maximum at 28 days (more than 90\%). The insecticidal action of $P$. crispum essential oil might be attributed to the toxicological properties of the chemical components of the oil that can have various effects on the respiratory and gastroenterology systems of the insects (Mahmoodi et al., 2014). Gruszecki (2009) reported that the main components of parsley leaf essential oil are $\alpha$-pinene $(25.5 \%), p$-cymenene (17.7\%), $\beta$-myrcene (16.9\%), $\beta$-phellandrene (15.2\%) and $\beta$-pinene (9.6\%). Its efficacy has been reported against several insects such as adults of Trialeurodes vaporariorum (Westwood) (Mahmoodi et al., 2014).

Effectiveness of different organophosphate insecticides, including diazinon, has been evaluated against scale insects in several previous studies. Diazinon inhibits the cholinesterase in the target pests and shows satisfactory effect against scale insects in fruit, ornamental and cut flower crops (Kwaiz, 1999).

In conclusion, A. calamus oil and thiamethoxam + chlorantraniliprole oil were proved as promising compounds tested for the first time in controlling C. rusci on $R$. simplex, compared to the recommended compound of mineral oil.

\section{Literature Cited}

Abbas, M., Hafeez, F., Ali, A., Farooq, M., Latif, M., Saleem, M. and Ghaffar, A. 2014. Date palm white scale (Parlatoria blanchardii $\mathrm{T}$ ): a new threat to date industry in Pakistan. Journal of Entomology and Zoology Studies, 2(6): 49-52.

Abd-Rabou, S., Badary, H. and Ahmed, N. 2012. Control measures of two soft scale insects (Hemiptera: Coccidae) infesting guava and mango trees in Egypt. The Journal of Basic and Applied Zoology, 65: 55-61.

Abdul-Hafeez, E.Y. and Egorov, M.A. 2012. Chromatographic analyse of volatile organic compounds in essential oil of Acorus calamus L. rhizome. Assiut Journal of Agricultural Sciences 43 (special issue):

Ahmed, M.A. 2005. Recommendation of four systemic insecticides for control of the green date palm pit scale insect (Asterolicanium phoenicis Rao) (Homoptera: Asterolicaniidae) using two methods of application. Proceedings of 72nd meeting of the pest and diseases committee, Wad Medani, Sudan 2005, 24.

Al-Momany, A. and Al-Antary, T. 2008. Pests of Garden and Home. 2nd edition, Jordan University Publications, Amman, Jordan pp 518.

Aly, A.G, Mohamed, Z.K. and Helmy, E.I. 1984. Efficiency of some local spray oils as summer application against Pulvinaria psidii Mask. Agricultural Research Review, 62: 163-167.

Anonymous, 2015. Ruellia simplex 'Purple Showers'. Missouri Botanical Garden website, http:// www.missouribotanicalgarden.org/PlantFinder/PlantFinder-Details. aspx?kempercode $=c 952$

Awamleh, R.A.A., Bilal, H.M. and Al-Antary, T.M. 2009. Evaluation of the efficacy of conventional and non-conventional insecticides on Fig Wax Scale Ceroplastes rusci L. (Homoptera: Coccidae) and its parasitoid, Scutellista cyanea M. (Hymenoptera: Pteromalidae). Jordan Journal of Agricultural Science, 5(2): 178-190.

Bakkali, F., Averbeck, S., Averbeck, D. and Idaomar, M. 2008. Biological effects of essential oils- A review. Food and Chemical Toxicology, 46: 446-475.

Blank, R.H., Olson, M.H., Gill, G.S.C. and Dow, B.W. 1997. Timing of insecticide applications for control of soft wax scale (Homoptera: Coccidae) on citrus. New Zealand Journal of Crop and Horticultural Science, 25(4): 311-317.

Chandel, B.S., Chauhan, R.R.S. and Kumar, A. 2001. Phagodeterent efficacy of rhizome extract of Sweet flag, Acorus calamus against Tribolium castaneum. Indian Journal of Entomology, 63(1): 8-10.

Clevenger, J.H. 1928. Apparatus for the determination of volatile oil. Journal of American Pharmaceutical Association, 17: 346.

Cordova, D., Benner, E.A., Sacher, M.D., Rauh, J.J., Sopa, J.S., Lahm, G.P., Selby, T.P., Stevenson, T.M., Flexner, L., Gutteridge, S., Rhoades, D.F., Wu, L., Smith, R.M. and Tao, Y. 2006. Anthranilic diamides: a new class of insecticides with a novel mode of action, ryanodine receptor activation. Pesticide Biochemistry and Physiology, 84: 196-214.

Cranshaw, W.S. and Baxendale, B. 2011. Insect Control: Horticultural Oils. Colorado State Univ., http:// www.ext.colostate.edu/pubs/insect/05569.html

Davidson, N.A, Dibble, J.E., Flint, M.L., Marer, P.J. and Guye, A. 1991. Managing insects and mites with spray oils. Univ. of Calif. Pub. 3347, Oakland.

Deng, J., Wang, X.B., Yu, F., Zhou, Q.S., Bernardo, U., Zhang, Y.Z. and Wu, S.A. 2015. Rapid diagnosis of the invasive wax scale, Ceroplastes rusci Linnaeus (Hemiptera: Coccoidea: Coccidae) using nested PCR. Journal of Applied Entomology, 139: 314-319. 
Dere, S., Gunes, T. and Sivaci, R. 1998. Spectrophotometric Determination of Chlorophyll - A, B and Total Carotenoid Contents of Some Algae Species Using Different Solvents. Turkish Journal of Botany, 22:13-17.

Ezcurra, C. and Daniel, T.F. 2007. Ruellia simplex, an older and overlooked name for Ruellia tweediana and Ruellia coerulea (Acanthaceae). Darwiniana, 45: 201-203.

Franco, J.C., Zada, A., Mendel, Z. 2009. Novel approaches for the management of mealybug pests. p. 233-278. In: "Biorational Control of Arthropod Pests Application and Resistance Management" (I. Ishaaya, A.R. Horowitz, eds.). Springer, Netherlands, $408 \mathrm{pp}$.

Gilman, E.F. 1999. Ruellia brittoniana, Fact Sheet FPS513. Environmental Horticulture Department, Florida Cooperative Extension Service, Institute of Food and Agricultural Sciences, University of Florida. 8 July 2007. <http://edis.ifas.ufl. edu/fp513>.

Gruszecki, R. 2009. The effect of growth stage on essential oil composition of 'Hamburg' parsley. Acta Horticulturae, 826: 391-396.

Helmy, E.I, Yousef, F.A., El-Deeb, W. and Ibrahim, F.A. 1992. Effect of certain mineral oils on the Citrus purple scale insect, Lepidosaphes beckii (Mewm.) and their influence on plant structure. Egyptian Journal of Agricultural Research, 70(3): 817-825.

Henderson, C.F. and Tilton, E.W. 1955. Test with acaricides against the brown wheat mite. Journal of Economic Entomology, 48: 157-161.

Hossain, M.S., Zaman, S., Haque, A.B.M.H., Bhuiyan, M.P.I., Khondkar, P. and Islam, M.R. 2008. Chemical and pesticidal studies on Acorus calamus rhizomes. Journal of Applied Science Research, 4(10): 1261-1266.

Ibrahim, F.A.M. 1990. Morphological effects of mineral oils used in the control of scale insects on citrus trees. M.Sc. Thesis, Fac. Agric., Cairo Univ., $127 p p$.

Ismail, I.A., Abdel-Rahaman, R.S. and Abdel-Raheem, M.A. 2015. Influence of some essential oils, chemical compounds and their mixtures against Ceroplastes rusci L. and Asterolcanium pustolans Cock on fig trees. International Journal of ChemTech Research, 8(9): 187-195.

Koul, O., Smirle, M.J. and Isman, M.B. 1990. Asarones from Acorus calamus L. oil: Their effect on feeding behavior and dietary utilization in Peridroma saucia. Journal of Chemical Ecology, 16: 1911-1920.

Krishnan, P., Ravi I. and Nayak, S.K. 1996. Methods for determining leaf chlorophyll content of rice: $A$ reappraisal. Indian Journal of Experimental Biology, 34: 1030-1033.

Kwaiz, F.A.M. 1999. Ecological and toxicological studies on the mango soft scale, Kilifia acuminata (Signoret) with special reference to insecticide residues in Mango fruits. Ph. D. Thesis, Fac. of Agric, Cairo Univ., 171 pp.

La Notte, P., Buzkan, N., Choueiri, E., Minafra, A. and Martelli, G.P. 1997. Acquisition and transmission of grapevine virus A by the mealybug, Pseudococcus longispinus. Journal of Plant Pathology, 78: 79-85.

Lahm, G.P., Selby, T.P., Freudenberger, J.H., Stevenson, T.M., Myers, B.J., Seburyamo, G., Smith, B.K., Flexner, L., Clark, C.E. and Cordova D. 2005. Insecticidal anthranilic diamides: a new class of potent ryanodine receptor activators. Bioorganic and Medicinal Chemistry Letters, 15: 4898-4906.

Liu, X.C, Zhou, L.G., Liu, Z.L. and Du, S.S. 2013. Identification of Insecticidal Constituents of the Essential Oil of Acorus calamus Rhizomes against Liposcelis bostrychophila Badonnel. Molecules, 18: 5684-5696.

Mahmoodi, L., Valizadegan, O. and Mahdavi, V. 2014. Fumigant toxicity of Petroselinum crispum L. (Apiaceae) essential oil on Trialeurodes vaporariorum (Westwood) (Hemiptera: Aleyrodidae) adults under greenhouse conditions. Journal of Plant Protection Research, 54(3): 294-299.

Miller, F. and Uetz, S. 1998. Evaluating biorational pesticides for controlling Arthropod pests and their phytotoxic effects on greenhouse crops. HortTechnology, 8(2): 185-192.

Mohamed, H.Th., Mohamed, I.A, Abou-Elhagag, G.H. and Saba, R.M. 2015. Toxicity and field persistence of thiamethoxam and dinotefuran against cabbage aphid, Brevicoryne brassica L. (Homoptera: Aphididae) under laboratory and field conditions. Journal of Phytopathology and Pest Management, 2(2): 20-26.

Mulugeta, T., Unnithan, C.R. and Tesfay, D. 2015. Phytochemical screening, characterization and biological activities of Petroselinum crispum (Parsley) leaf oil. World Journal of Pharmacy and Pharmaceutical Sciences, 4: 142-151.

Nada, M.A., Abd-Rabou, S., and Hussien, G.E. 1990. Scale insects infesting mango trees in Egypt (Homoptera: Coccoidea). In: Proceedings of ISSIS, vol. VI, Part II, pp. 133-134.

Nair, S. and Thomas, J. 2001. Evaluation of the chemosterilant effect of Acorus calamus L. extracts on Melon fly, Bactrocera cucurbitae Coq. Journal of Tropical Agriculture, 39: 145-148.

Petropoulos, S.A., Daferera, D., Akoumianakis, C.A., Passam, H.C. and Polissiou, M.G. 2004. The effect of sowing date and growth stage on the essential oil composition of three types of Parsley Petroselinum crispum. Journal of the Science of Food and Agriculture, 84(2): 1606-1610

Ramos-Ocampo, V.E. and Hsia, M.T.S. 1986. Toxicity and chemosterilant activity of Calamus oil and asarone analogs to the kelp fly, Coelopa frigida (F.). Philippine Entomologist, 6: 485-494.

Saglam, O., Athanassiou, C.G. and Vassilakos, T.N. 2013. Comparison of spinetoram, imidacloprid, 
thiamethoxam and chlorantraniliprole against life stages of Tribolium confusum Jacquelin du Val (Coleoptera: Tenebrionidae) on concrete. Crop Protection, 53: 85-95.

Satar, G., Ateş, H.F. and Satar, S. 2013. Effects of different insecticides on life stages of Planococcus citri Risso (Hemiptera: Pseudococcidae). Integrated Control in Citrus Fruit Crops. IOBC-WPRS Bulletin, 95: 183-190.

Sattelle, D.B, Cordova, D. and Cheek, T.R. 2008. Insect ryanodine receptors: molecular targets for novel pest control chemicals. Invertebrate $\mathrm{Neu}$ roscience, 8: 107-119.

Saxena, B.P, Koul, O., Tikku, K. and Atal, C.K. 1977. A new insect chemosterilant isolated from Acorus calamus L. Nature, 270: 512-513.

Snedecor, G.W. and Cochran, W.G. 1989. Statistical Methods. 8th eds., lowa State University Press, lowa, USA.

Steel, R.G. and Torrie, T.H. 1982. Principles and Procedures of Statistics. McGraw-Hill International Book Company, $3^{\text {rd }}$ Edn., London.
Taha, A.K., Khalid, O.A.M.E., Idris, T.I.M. and Sidahmed, O.A.A. 2012. Argel (Solennostemma argel) applications for control of the date palm green pit scale insect (Asterolicanium phoenicis rao) and yield enhancement. Journal of Agricultural and Biological Science, 7(6): 380-385.

Thangapandian, K., Muthusamy, M. and Vimal, P. 2011. Efficacy of the plant products Acorus calamus, Piper longum, and Econeem against the Larvae of Tobacco Caterpillar Spodoptera litura Fab. (Lepidoptera: Noctuidae). Journal of Research in Biology, 7: 490-493.

Vu, N.T, Eastwood R., Nguyen, C.T. and Pham, L.V. 2006. The fig wax scale Ceroplastes rusci (Linnaeus) (Homoptera: Coccidae) in southeast Vietnam: pest status, life history and biocontrol trials with Eublemma amabilis Moore (Lepidoptera: Noctuidae). Entomological Research, 36: 196-201.

Received: 6 November 2016; Accepted: 12 January 2017

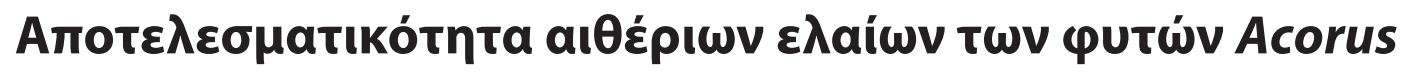

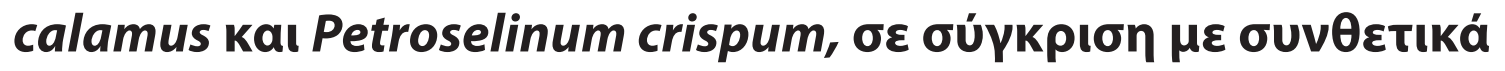

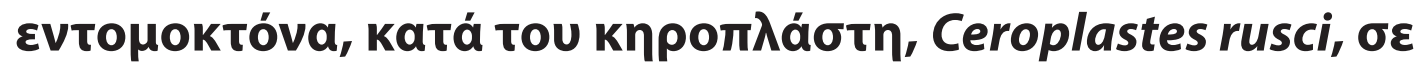

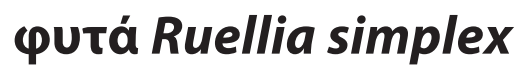

\author{
I.A. Mohamed, G.S. Mohamed, E.Y. Abdul-Hafeez kaı O.H.M. Ibrahim
}

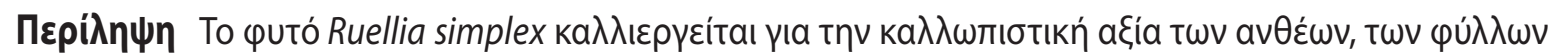

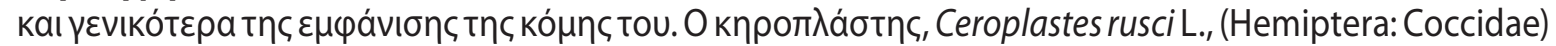

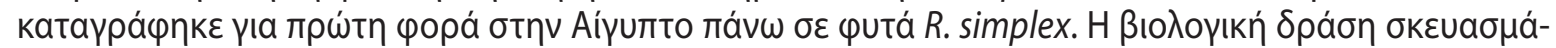

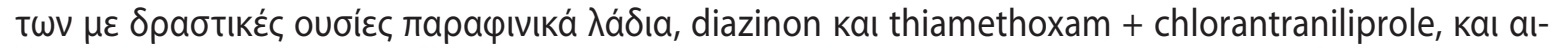

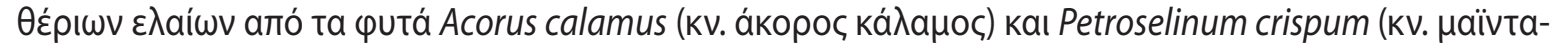

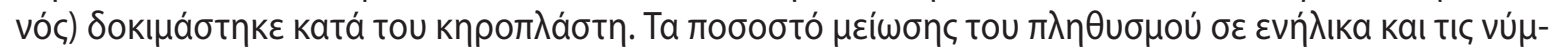

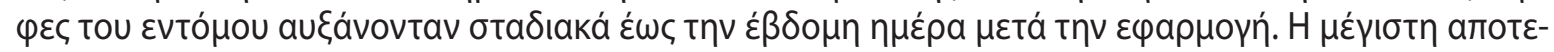

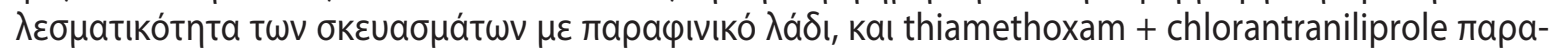

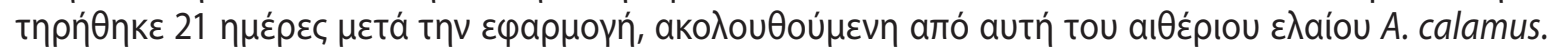

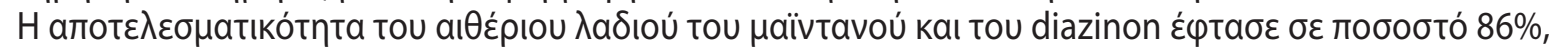

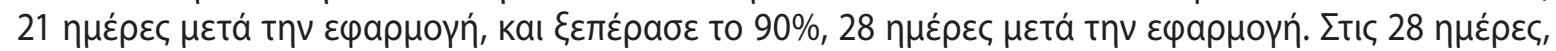

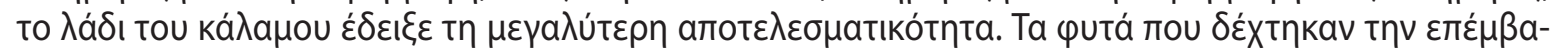

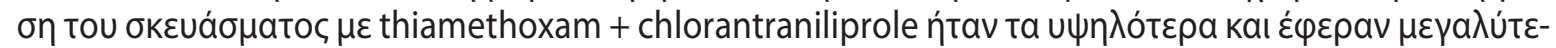

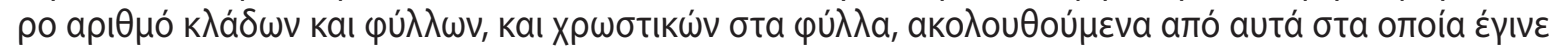

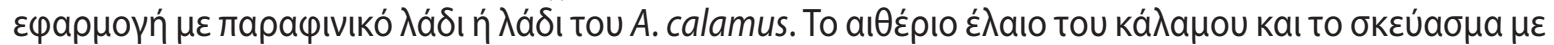

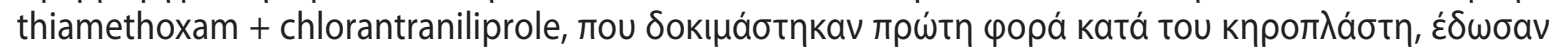

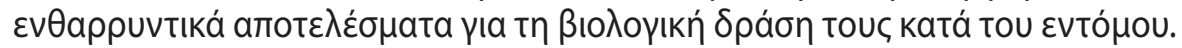

